University of Nebraska - Lincoln

DigitalCommons@University of Nebraska - Lincoln

Faculty Publications, UNL Libraries

Libraries at University of Nebraska-Lincoln

$7-2010$

\title{
Library Services for Great Plains IDEA Consortial Students
}

Kate E. Adams

University of Nebraska - Lincoln, kadams1@unl.edu

Mary Cassner

University of Nebraska at Lincoln, mcassner1@unl.edu

Follow this and additional works at: https://digitalcommons.unl.edu/libraryscience

Part of the Library and Information Science Commons

Adams, Kate E. and Cassner, Mary, "Library Services for Great Plains IDEA Consortial Students" (2010). Faculty Publications, UNL Libraries. 216.

https://digitalcommons.unl.edu/libraryscience/216

This Article is brought to you for free and open access by the Libraries at University of Nebraska-Lincoln at DigitalCommons@University of Nebraska - Lincoln. It has been accepted for inclusion in Faculty Publications, UNL Libraries by an authorized administrator of DigitalCommons@University of Nebraska - Lincoln. 
Published in Journal of Library Administration 50:5-6 (July 2010), pp. 414-424; doi: 10.1080/01930826.2010.488584 Copyright (C) K. E. Adams \& M. Cassner; published by Routledge/Taylor \& Francis. Used by permission.

\title{
Library Services for Great Plains IDEA Consortial Students
}

\author{
Kate E. Adams and Mary Cassner \\ University of Nebraska-Lincoln, Lincoln, NE, USA \\ Corresponding author - K. Adams, University Libraries, University of Nebraska-Lincoln, \\ Lincoln, NE 68588-4100, USA. Email kadams1@unl.edu
}

\begin{abstract}
The Great Plains Interactive Distance Education Alliance (Great Plains IDEA) is a multistate alliance of 11 universities that offer online master's degrees and certificate programs in human sciences. The authors surveyed librarians at Great Plains IDEA institutions to learn how each library provides distance services to students enrolled in Great Plains IDEA courses offered through this interinstitutional alliance.
\end{abstract}

Keywords: distance library services; Great Plains Interactive Distance Education Alliance; library cooperation; online graduate programs

\section{Introduction}

This article discusses library services and resources for students enrolled in online courses offered through the Great Plains Interactive Distance Education Alliance (Great Plains IDEA). Through this interinstitutional alliance of 11 universities with human sciences colleges, participating institutions deliver fullyonline master's degree and postbaccalaureate certificate programs in community development, dietetics, family and consumer sciences education, family financial planning, food safety and defense, gerontology, merchandising, and youth development. Universities in 11 states share graduate courses in order to deliver those fully-online programs and certificates. A student is admitted to one participating institution as a "home institution," and takes Great Plains IDEA courses from other participating institutions as well as the home institution.

The Standards for Distance Learning Library Services, which were approved by the Association of College \& Research Libraries Board of Directors in July 
2008 , state that each student is entitled to library resources and services of the respective institution regardless of method of course delivery or location. The standards specifically mention that each college or university in a multi-institutional cluster has the responsibility for meeting the library needs at the collective site (Association of College \& Research Libraries, 2008). Of interest to the authors is the distance library services program at academic libraries for consortial students who are enrolled in multi-institutional distance graduate programs. Since the University of Nebraska-Lincoln (UNL) is a member of the Great Plains IDEA, the authors chose to explore how each library in the alliance provides distance services to students who are enrolled in the interinstitutional courses.

Consortial associations have been part of the academic landscape since the 1960s, serving as a means for colleges and universities to achieve mutual goals and share resources. Later, universities and colleges established consortia to sustain programs, especially those in low-enrollment, specialized fields. According to the Association for Consortium Leadership, there are more than 125 -member consortia in the United States varying both in size and purpose (Glazer-Raymo, 2003).

The authors studied distance library services available to students enrolled in consortial graduate programs and certificates through Great Plains Interactive Distance Education Alliance (IDEA). We developed a survey that was sent to distance librarians at libraries of the member institutions. Research questions included: (a) what library services and resources are offered to Great Plains IDEA students at each institution?; (b) to what degree are library services for consortial distance students similar across the various institutions?; and (c) what issues are there for service delivery to consortial students taking online courses in the Great Plains IDEA programs?

Findings from the study will contribute to the understanding of academic libraries' current practice in serving students who are enrolled in interinstitutional distance graduate programs. Findings can inform teaching faculty and distance education administrators of specific issues related to consortial students taking distance courses. The study results will add to the limited research base regarding library service delivery to consortial distance students in graduate programs.

\section{Literature Review}

The authors reviewed the literature on multistate consortia of universities that offer distance delivered graduate programs. In particular we wanted to find articles and Web sites that addressed library service to distance learners in graduate online programs. Our search proved to be a challenge. Many consortia, such as the University of Texas's Telecampus, Electronic University Consortium of South Dakota, State University of New York's Learning Network, 
and West Virginia Virtual Learning Network, serve students within the state. The Tri-College Consortium of three institutions in Moorhead, Minnesota, and Fargo, North Dakota, has offered a graduate program in educational leadership since 1974. While courses are increasingly delivered online, the program model is residential, and students visit the library on-site at the institutions.

The Western Governors University (WGU) offers several online masters in education. WGU students have access to a central online library with several major databases, online catalog, and ILLiad interlibrary loan service from the University of New Mexico General Library.

The Biostatistics Collaboration of Australia (BCA) consortium began in 2001 with eight universities offering a graduate program in biostatistics via distance. BCA participants collaborated to develop and deliver the program to meet "the need for workforce and academic capacity building in biostatistics" (Heller, Forbes, Dear, \& Jobling, 2008, p. 321). Each consortial institution recognizes courses taught by BCA members. Distance students enroll in one of the participating universities and take courses taught by instructors from BCA institutions. Library service is available from the home institution; there is no mention of distance learning library services on the Web site (http:// www.bca.edu.au/).

\section{Case Study}

The Great Plains IDEA (http://www.hsidea.org) is a multistate alliance of 11 universities with human sciences colleges offering fully-online graduate programs. The alliance was formed in 1994 when academic deans from the 8 original institutions met to discuss an idea. The College of Human Resources and Family Sciences at the UNL had implemented an interdepartmental master's program via distance education, and the dean asked if other institutions had distance education graduate courses that could be shared. The idea took hold, but there were obstacles such as "lack of Internet connectivity for rural professionals (the target demographic), an absence of commercially available and easy-to-use instructional software, and a paucity of distance education experience on the part of the faculty" (Moxley \& Maes, 2007, p. 162). Alliance initiatives were developed to inform faculty of the changing marketplace for graduate education, train faculty in how to use technology for graduate courses at a distance, and develop a marketplace for shared distance education courses (Moxley \& Maes, 2007). A team of interinstitutional academic faculty soon responded with a proposal for a family financial planning program.

Implementation would need more than committed human sciences college faculty and administrators. The alliance members brought graduate deans, registrars, distance education administrators, and finance officers into the discus- 
sion. Graduate deans developed principles: interinstitutional partners are equal (graduate faculty status at one institution is recognized by all); institutional differences are accepted (course numbers, degree titles, and faculty workload are institutional prerogatives); and student navigation is easy (the student's home university provides administrative and support services) (Moxley \& Maes, 2007). Principles were developed, and policies then followed. In 2002, 10 universities approved alliance bylaws and a Memorandum of Agreement.

The Great Plains IDEA programs are based on student demand and faculty interest. Faculty at one or more institutions propose and develop the curriculum, and interested partners are identified. The Great Plains IDEA Board reviews the draft proposal and seeks faculty feedback from each participating institution. A market analysis is conducted. By 2004 youth development and gerontology graduate programs were added ("Program Alliance Pools Expertise," 2004).

In January 2000, the UNL College of Human Resources and Family Sciences Web site stated: "The Great Plains IDEA is a regional consortium of land grant institutions that provide graduate and undergraduate education in family and consumer sciences through extended education programs" (UNL, 2000, para. 2). Marketing efforts included a brochure announcing the family financial planning master's and certificate programs. The brochure stated that faculty from universities in six states had developed shared graduate courses in order to deliver graduate programs and certificates in this specialized field.

Later in 2000, the libraries at UNL were informed that a UNL faculty member would be teaching a course as part of the family financial planning program, which was to be offered in conjunction with five other universities. The libraries had been providing service to distance learners enrolled in the interdepartmental master's degree in human resources and family sciences (HRFS) via distance education since $1994 .^{1}$ The dean of libraries stated that library services would be extended to consortial students when enrolled in a consortial course taught by a UNL faculty member. Service for the Great Plains IDEA consortial students would be modeled on the current services offered to UNL distance learners enrolled in graduate programs.

\section{Methodology}

The authors' research is based on a survey of distance librarians at Great Plains IDEA universities. This consortial alliance, consisting of eleven universities with human sciences colleges, currently offers Master's degree and certificate programs in community development, dietetics, family and consumer sciences education, family financial planning, food safety and defense, gerontology, merchandising, and youth development. 
Research questions for the study included: What Great Plains IDEA programs are offered at each institution? What services and resources does the library offer to students enrolled in Great Plains IDEA online courses offered by the university? What methods does the library use to communicate with consortial students? How do librarians at the institution use course management software for instruction to consortial students? Are there service delivery concerns for Great Plains IDEA students? What additional methods can libraries use to support consortial students? Finally, does the library have a Web page for distance students?

The survey instrument consisted of 11 questions. Four questions were completely open-ended. Six questions were partially close-ended, offering respondents the opportunity to mark suggested responses as well as expand on answers through comments. One close-ended question asked respondents to mark each Great Plains IDEA program offered by their institution.

The survey and sample cover letter were submitted to the University of $\mathrm{Ne}$ braska-Lincoln's Institutional Review Board for required approval. Survey questions were then formatted using Flashlight Online (version 1.0, Washington State University, Spokane, WA) software to create the survey instrument.

The authors intended to survey one distance librarian at each of the participating Great Plains IDEA institutions. We began by examining the library Web pages. As of November 2009, 10 of the 11 libraries had a distance education services page. However, only 4 of those pages identified one individual, or, in two instances, a group of individuals, as distance librarian contacts. Additional names were located by searching libraries' staff directories and subject librarian lists. In several cases, phone calls were made.

Since the survey would be distributed to only one individual at each institution, we sent advance notice of the upcoming survey by email to the list of prospective respondents. We asked for a reply within 1 week. In two instances, recipients referred us to another individual.

An email message was initially sent in November 2009, inviting the designated population to participate in the online survey. The message served as a cover letter, outlining the research study. Respondents were able to click on the link attachment to the online survey. A second email message was sent in December as a final opportunity for participation. Survey recipients were from the following institutions: Colorado State University, Iowa State University, Kansas State University, Michigan State University, University of Missouri, Montana State University, University of Nebraska-Lincoln, North Dakota State University, Oklahoma State University, South Dakota State University, and Texas Tech University.

The survey was anonymous as it did not ask for information that could identify individuals, institutions, or e-mail addresses. As each online survey was submitted, the data was sent to a secure server operated by Flashlight Online. Both raw and compiled data were collected and analyzed by the researchers. 


\section{Results}

Ten of the 11 librarians invited to participate in the study submitted survey responses through the Flashlight Online link. Below are the questions asked in the survey and answer results. Frequently respondents used the comments boxes to expand on their responses. Selected comments are included with the related question.

Q1. Mark each Great Plains IDEA program offered by your institution.

- 2 Community development

- 4 Dietetics

- 3 Family and consumer sciences education

- 4 Family financial planning

- 0 Food safety and defense

- 2 Gerontology

- 2 Merchandising

- 1 Youth development

These numbers are lower than the program listings on the Great Plains IDEA Web site (http://www.hsidea.org/; see Discussion and Conclusion section).

Q2. Does your library offer distance library services to students enrolled in Great Plains IDEA online courses offered by your university?

- 9 Yes

- 1 No

Six librarians offered comments. Four respondents reported that all students registered for courses through their universities have access to library services. One added that while she does not check if students are enrolled in Great Plains IDEA courses, she does verify that they are registered as current students. Another librarian indicated that while Great Plains IDEA distance students are not identified as a group, distance services are provided to students who live at least at least 50 miles from campus. One librarian reported that distance services are available to consortial students when faculty from her university teach a Great Plains IDEA course.

Two responded that they were not familiar with the Great Plains IDEA program, but one stated she has worked with students in some of the courses listed. 


\section{Q3. Mark each service your library provides to Great Plains IDEA consortial} students.

- 9 Reference

- 9 Research assistance consultation with Liaison/Subject Specialist Librarian

- 6 Electronic reserves

- 7 Document delivery

- 6 Traditional interlibrary loan

Five respondents provided comments. Two confirmed that traditional and distance students enrolled at their institutions have access to all services including those listed above. One librarian stated that reference and research assistance services are open to the public and available virtually to distance students. Another librarian sends a welcome e-mail to consortial students enrolled through her institution. Document delivery of materials, usually in electronic format, is available to consortial students through her library.

Q4. Mark each resource your library provides to Great Plains IDEA consortial students.

- 7 Online journal article indexes

- 7 Full-text electronic journals

- 8 Dissertations

- 7 E-books

- 5 Online bibliographic citation management systems

Three respondents reported that their library uses End Note as a citation management system. One respondent stated that the library currently does not have an online citation management system.

Q5. Mark each research assistance tool your library provides to Great Plains IDEA consortial students.

- 4 Tutorials or learning modules

- 7 Subject or discipline-specific guides

- 2 Course-specific Web pages or guides

Two librarians reported that they do not have tutorials or guides but would create these if asked by class instructors. Another stated that their library has very few of these tools and none for the aca- 
demic programs offered through Great Plains IDEA programs. One librarian reported her library uses LibGuides, while another has tutorials on topics such as preparing literature reviews and using EndNote Web. That librarian also indicated that subject specialist librarians have individual Web pages with subject-specific guides. One noted that distance students receive equivalent services and resources including the provision of synchronous library instruction and research consultation via Adobe connect.

Q6. Does your library have a Web page for distance students?

- 8 Yes

- 2 No

One librarian reported that the distance education Web page has been streamlined to reduce redundancy on library Web pages.

Q7. Mark each method your library uses to communicate with Great Plains IDEA consortial students.

- 2 Twitter

- 2 Facebook/MySpace

- 2 Blogs

- 10 E-mail

- 1 Skype or other VOIP software

- 9 Traditional phone

- 10 Ask-a-librarian service

- 2 Web conferencing

Several respondents indicated that communication mediums are not necessarily marketed to Great Plains IDEA students, but are certainly available to the distance learners. Communication methods included Ask Us page enabling instant messaging chat, toll free phone numbers, and Crafty Syntax Live Help. One respondent stated that various communication methods could be available if requested by instructors.

Q8. How do librarians at your institution use course management software for instruction to students enrolled in Great Plains IDEA consortial courses?

Four librarians indicated that they create library tutorials or research guides for use in Blackboard, ANGEL, or WebCT. Three respondents use Desire2Learn (D2L). One reports "the library's pres- 
ence on D2L provides a Meebo widget for chat reference interactions and links to the library's home page and the library's distance library services page." Another librarian indicated that they use D2L to refer students to liaison librarians and other course-specific assistance. One librarian stated that course instructors have the option of embedding librarians in their D2L courses with a librarian tab.

\section{Q9. What issues are there for service delivery to students in the Great Plains IDEA consortial programs?}

Three respondents stated that while anyone can access the library Web sites and online catalog, only students registered at their universities are eligible for library services. One said: "Interacting efficiently with Great Plains IDEA students may be more difficult because I'm not sure these students have a university email address, and the appropriate IDS and passwords to access our databases and distance services. If they email us or call us on our toll-free number, we can give them access information."

Similarly, another respondent said that Great Plains IDEA students can become confused when the proxy server asks them to type in the student ID number of another consortial university.

Several stated that traditional interlibrary loan of books does not work for students living out of town due to the time delay of mailing materials. Another considered document delivery and the costs associated with it to be an issue. Also, one librarian indicated the program needs increased promotion and marketing or awareness.

\section{Q10. What are additional ways that libraries can support students enrolled in Great Plains IDEA consortial programs?}

Comments included:

- More participation with Blackboard, either on a course-by-course basis or consortial program basis. The distance librarian and liaison librarian could work with GP IDEA faculty to promote use of libraries on the Great Plains IDEA consortial programs Web pages.

- Creating Web pages listing contact information and basic services and resources offered. These links would be available from all online courses.

- $\quad$ Lots of ways if we know the courses that are being offered.

- Teaching resource use via IVN or Blackboard.

- Tutorials that clarify the process of accessing print and electronic materials for distance students.

- More open access materials.

- Providing consortial access to electronic collections behind a pay wall. 


\section{Q11. Additional comments related to providing library services for Great Plains IDEA consortial students.}

One respondent commented that the library is planning to obtain LibGuides in support of distance and traditional students. Another stated "we try to treat all the students the same-providing the same services to all."

\section{Discussion and Conclusion}

One of the broad themes of the survey results relates to awareness. Two respondents were unfamiliar with the Great Plains IDEA organization, although one has assisted distance learners enrolled in courses offered through the consortium. In marking which Great Plains IDEA programs are offered at their institution, respondents underreported the specific programs in which their institution participates. For example, eight institutions offer Family Financial Planning, while four respondents marked that program. Four institutions offer Youth Development, and only one respondent checked that program. Course program information is available at http://www.hsidea.org/.

Unfamiliarity may be partly due to the complexity of large academic organizations. The name of the consortial program may differ from the name of the administrative home department that offers courses. For instance, at UNL, the community development program is offered through the Agricultural Economics Department, and the family financial planning program is offered through the Family and Consumer Sciences Department.

A second broad theme relates to communication. Open communication has been essential to shared curriculum development and local institutional practice. The consortium's policy and procedure manual lists the library as a component for service to distance students. Including distance librarians in meetings with Great Plains IDEA faculty and administrative staff could be beneficial.

All respondents indicated that they use e-mail and the ask-a-librarian service to communicate with Great Plains IDEA students. All but one librarian use the phone as a communication tool. Conversely, only two librarians indicated that they use Twitter, Facebook/My Space, blogs, and Web conferencing. Currently, only one librarian uses Skype or other VOIP software to communicate with his group of students. These results are similar to the authors' 2007 study of the subject specialist librarian's role in providing distance learning services (Cassner \& Adams, 2008).

From our examination of library Web pages, only four libraries identified one individual or group of individuals as distance librarian contacts. At other libraries, distance users are directed to a generic "contact us" via phone or email. Distance users are also pointed to a specific service such as ILLiad document delivery or reference assistance. This effort is changing the picture of how distance students contact the libraries. 
With the increase of hybrid and online courses and more students taking online courses, there is less distinction between the distance student population and residential students. The practice today among academic libraries is to make their services and resources transparent to the students. There may likely be a reduced emphasis on a "distance education" service. The ubiquitous use of Ask a Question suggests that the distinction between distance and residential is less important.

Survey results revealed that in most instances, Great Plains IDEA students do have access to equivalent services and resources received by other distance students. The survey has raised the respondents' awareness of the specialized population of distance learners.

The authors note that the small population group surveyed is a limitation to the study. A follow-up survey might have additional insights into service delivery to graduate students enrolled in interinstitutional distance programs.

\section{Note}

1. Cassner and Adams (1998) described the results of their survey of HRFS distance students in The Eighth Off-Campus Library Services Conference Proceedings.

\section{References}

Association of College \& Research Libraries (2008) Standards for distance learning library services. CERL News 69 , pp. 558-569.

Cassner, M. and Adams, K. Thomas, P. S. and Jones, M. (eds) (1998) Instructional support to a rural graduate population: An assessment of library services. The eighth off-campus library services conference proceedings: Providence, Rhode Island pp. 117-129. Central Michigan University , Mount Pleasant

Cassner, M. and Adams, K. (2008) The subject specialist librarian's role in providing distance learning services. Journal of Library Administration 48 , pp. 391-410.

Glazer-Raymo, J. Guthrie, J. W. (ed) (2003) Consortia in higher education. Encyclopedia of education 2nd ed., - Retrieved from http://galegroup.com/

Heller, G. Z. , Forbes, A. B. , Dear, K. B. G. and Jobling, E. (2008) Biostatistics @ distance: A model for successful multi-institutional delivery. The American Statistician 62 , pp. 321-328.

Moxley, V. and Maes, S. Johnstone, S. M. (ed) (2007) The Great Plains IDEA story. Advancing campus efficiencies: A comparison for campus leaders in the digital era pp. 161-165. Anker, Boston, MA

Program alliance pools expertise, resources to meet student demand (2004, July 1) Distance Education Report 8:13, pp. 3-6.

University of Nebraska-Lincoln. College of Human Resources and Family Sciences (2000, January 24) - Great Plains IDEA: Interactive Distance Education Alliance 